Acta vet. scand. $1984,25,280-296$.

From the State veterinary Institute for Virus Research, Lindholm, Denmark.

\title{
AN ENZYME-LINKED IMMUNOSORBENT ASSAY (ELISA) FOR THE PRIMARY DIAGNOSIS OF FOOT-AND-MOUTH DISEASE

\author{
CHARACTERIZATION AND COMPARISON WITH \\ COMPLEMENT FIXATION
}

By

P. Have, J. C. Lei and K. Schjerning-Thiesen

HAVE, P., J. C. LEI and K. SCHJERNING-THIESEN: An enzymelinked immunosorbent assay (ELISA) for the primary diagnosis of foot-and-mouth disease. Characterization and comparison with complement fixation. Acta vet. scand. 1984, 25, 280 - 296. - A sandwich type ELISA for foot-and-mouth disease (FMD) virus types $\mathrm{O}, \mathrm{A}$ and $\mathrm{C}$ was established, using a combination of rabbit anti-146 $\mathrm{S}$ and guinea pig hyperimmune antibodies. This method was found to be highly efficient for the detection of both $146 \mathrm{~S}$ particles and $12 \mathrm{~S}$ subunits. The ELISA was approximately 500 times more sensitive than complement fixation (CF) when examining epithelial samples of FMD vesicles. An early primary diagnosis of FMD was obtained by both CF and ELISA in 19 out of 21 confirmed cases. The remaining 2 cases were initially negative in CF but positive in ELISA.

FMD; virus; type $\mathrm{O}_{1}$; ty pe $\mathrm{A}_{10}$; type $\mathrm{C}$; double sandwich technique; $146 \mathrm{~S}$ particles; $12 \mathrm{~S}$ subunits;

field samples; sensitivity; specificity.

In recent years various enzyme immunoassays of foot-andmouth disease (FMD) virus have been described. These include typing of FMD virus (Crowther \& Abu Elzein 1979 a, b) and specific detection of $146 \mathrm{~S}$ virus particles ( $A$ bu Elzein \& Crowther 1979, Ouldridge et al. 1982). The typing of FMD virus $\mathrm{O}_{1}$ was found to be specific in the sense that no detectable reaction was obtained when equivalent amounts of type $A$ virus were examined by sandwich and indirect techniques (Crowther \& $\mathrm{Abu}$ Elzein 1979 b). Furthermore, the sandwich-technique could be used for the specific detection of $\mathrm{O}_{1} 146 \mathrm{~S}$ viral particles in the presence of $12 \mathrm{~S}$ subunits, using either anti-146 $\mathrm{S}$ or hyperim- 
mune guinea pig sera ( $A$ bu Elzein \& Crowther 1979). Similar results were obtained by using rabbit anti-146 $\mathrm{S}$ antibodies (Ouldridge et al. 1982).

In the present report an enzyme-linked immunosorbent assay (ELISA) for FMD virus types $\mathrm{O}, \mathrm{A}$ and $\mathrm{C}$ is described and charactized with respect to reaction with $146 \mathrm{~S}$ particles and $12 \mathrm{~S}$ subunits. Furthermore, its application during routine diagnostic work including a comparison with a complement fixation (CF) test is presented.

\section{MATERIALS AND METHODS}

Virus

FMD virus strains $\mathrm{O}_{1}$ (BFS 1860), $\mathrm{A}_{10}$ (Holland) and $\mathrm{C}$ (Denmark 61) were grown in BHK cells in suspension culture. Crude harvests were inactivated with binary ethylenimine and two-step concentrated with $6 \%$ polyethylenglycol (PEG). The $146 \mathrm{~S}$ particles were collected by sucrose-gradient centrifugation as previously described (Lei 1978).

Suspensions of $12 \mathrm{~S}$ subunits were produced by heating purified $146 \mathrm{~S}$ particles at $56^{\circ} \mathrm{C}$ for 2.5 hours and monitoring the product for absence of $146 \mathrm{~S}$ particles by gradient centrifugation.

Epithelial samples from cattle of type $\mathrm{O}, \mathrm{A}$ and $\mathrm{C}$ viruses, including field samples of type $O$, were prepared as 10 or $20 \%$ suspensions in veronal buffer after grinding with sand.

\section{Antisera}

Rabbit anti-146 S sera were prepared by 2 subcutaneous inoculations of $15 \mu \mathrm{g}$ of $146 \mathrm{~S}$ particles emulsified in Freund's incomplete adjuvant. The second inoculation was given after 4 weeks and followed by bleeding 10-12 days later.

Guinea pig hyperimmune sera against types $O_{1}, A_{10}$ and $C$ virus were produced as previously described (Schjerning-Thiesen 1964). The globulin fractions were precipitated by ammonium sulphate at $40 \%$ saturation and dissolved in distilled water to the original volume of serum.

To prepare monomeric guinea pig IgG, ammonium sulphate precipitates were dialysed against water, clarified by centrifugation and applied to a column of Bio-gel A $1.5 \mathrm{~m}$. Fractions corresponding to monomeric IgG were pooled and stored at $4^{\circ} \dot{\mathrm{C}}$. Absorption of rabbit IgG with guinea pig serum insolubilized with 


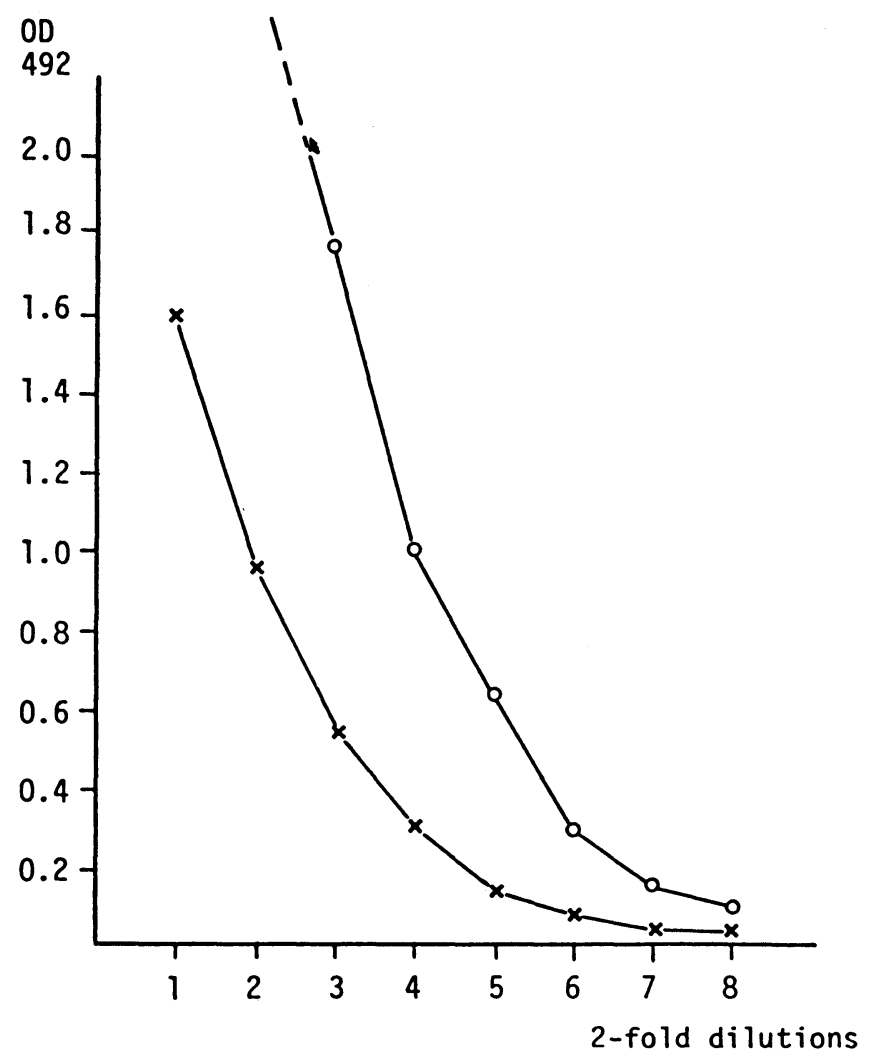

Fig u re $1 \mathrm{a}-\mathrm{b}$. Titration of $\mathrm{O}_{1}$ BFS virus in sandwich ELISA using hyperimmune guinea pig IgG type $O$ as catching antibody (step 1) and rabbit antiserum type $\mathrm{O}_{1} \mathrm{BFS}$ (step 3). a: titration of $\mathrm{O}_{1} \mathrm{BFS} 146 \mathrm{~S}$ particles $(x-X)$ and $12 \mathrm{~S}$ subunits $(\mathrm{O}-\mathrm{O})$ with rabbit antiserum and conjugate diluted in buffer containing normal guinea pig serum. b: titration of $146 \mathrm{~S}$ particles $(\triangle-\triangle)$ and $12 \mathrm{~S}$ units $(\square-\square)$ from (a) with rabbit antiserum and conjugate diluted in buffer containing $2.5 \%$ of each of guinea pig hyperimmune serum type $\mathrm{A}$ and $\mathrm{C}$. The curves from (a) are included for comparison. The first dilution contained $125 \mathrm{ng} / \mathrm{ml}$ of $146 \mathrm{~S}$ particles of the equivalent amount of $12 \mathrm{~S}$ subunits.

glutaraldehyde was done according to established methods (Ternynck \& Avrameas 1976).

Horseradish peroxidase-conjugated antibodies against species IgG were obtained commercially (DAKOPATTS, Copenhagen).

\section{Enzyme-linked immunosorbent assay}

Round-bottomed polystyrene microplates were used (NUNC, cat. 62.162 or immunoplate II). On a few occasions flexible poly- 


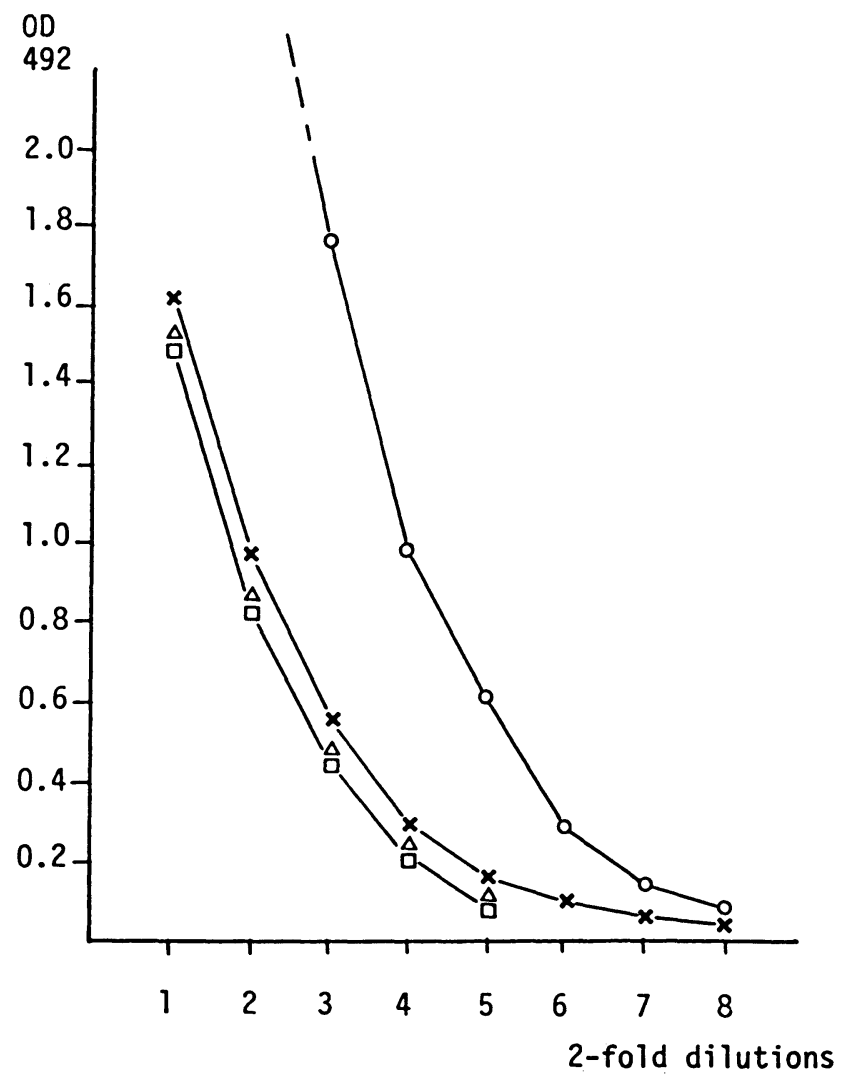

Figure 1 b.

vinyl microplates (Dynatech) were used in parallel for comparison.

A double sandwich technique was used to detect FMD virus. Unknown samples were always examined simultaneously in sandwiches for types $O, A$ and $C$. The sandwich comprised the following steps:

1. Adsorption of rabbit anti-FMD-virus IgG for 1 hour at $37^{\circ} \mathrm{C}$. The IgG was diluted 1:1000 in carbonate buffer $\mathrm{pH} 9.6$.

2. Reaction with virus (test sample) for $1 \mathrm{~h}$ at $37^{\circ} \mathrm{C}$.

3. Reaction with hyperimmune guinea pig IgG of the same type as used in (1) for $30 \mathrm{~min}$ at $37^{\circ} \mathrm{C}$. The guinea pig IgG was diluted 1:1000 in PBS-0.05\% Tween 20 containing $10 \%$ normal bovine serum and $5 \%$ normal rabbit serum.

4. Reaction with peroxidase-conjugated antibody to guinea pig 


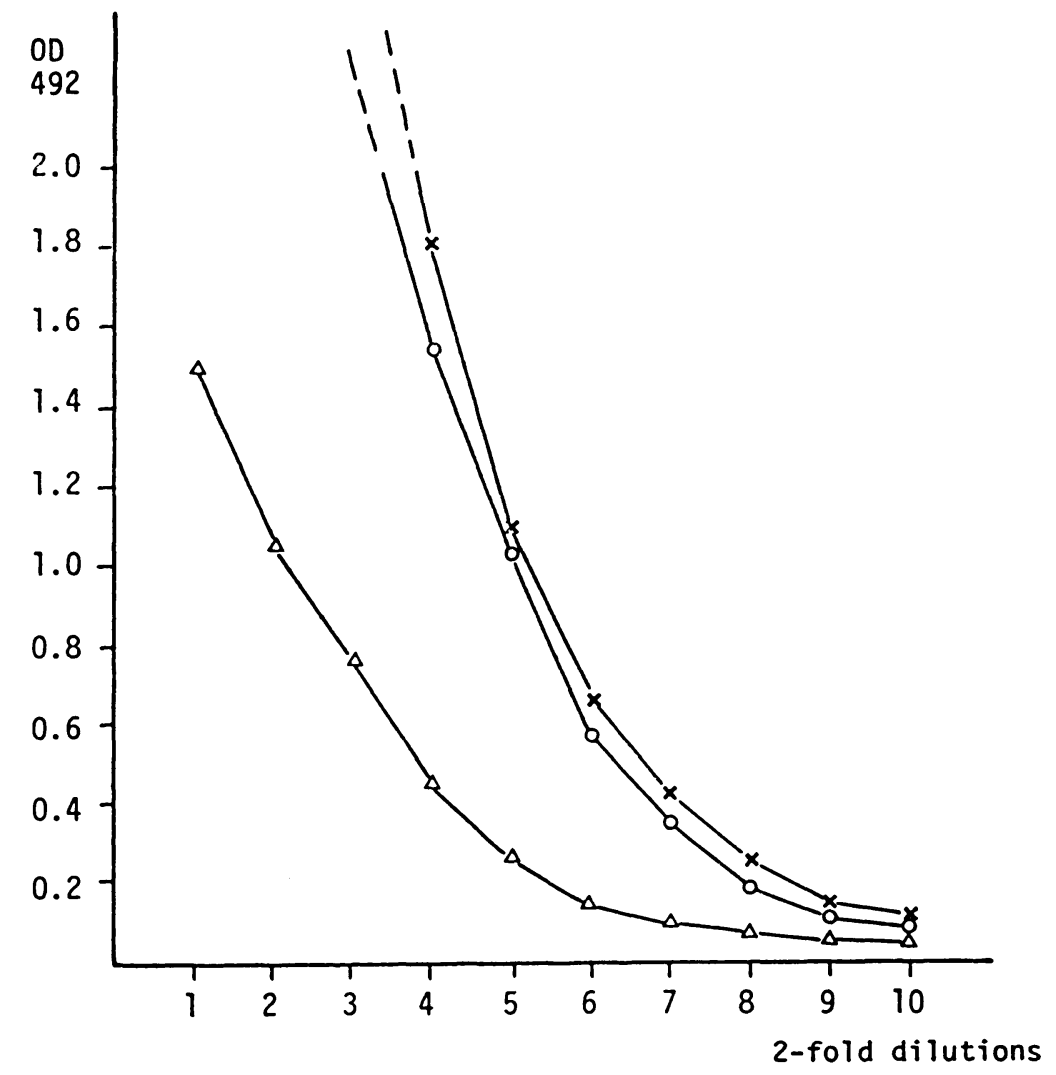

$\mathrm{F}$ i g u r e $2 \mathrm{a}$ - b. Titration of $\mathrm{O}_{1} \mathrm{BFS} 146 \mathrm{~S}$ particles (a) and $12 \mathrm{~S}$ subunits (b) in the same sandwich as in fig. 1. Rabbit $O_{1}$ BFS antiserum diluted in buffer containing normal guinea pig serum $(X-X)$ or hyperimmun guinea pig serum type $A$ and $C(O-O)$. Rabbit $C$ antiserum diluted in buffer with normal guinea pig serum $(\triangle-\triangle)$. The first dilution contained $2 \mu \mathrm{g} / \mathrm{ml}$ of $146 \mathrm{~S}$ particles or the equivalent amount of $12 \mathrm{~S}$ subunits.

IgG for $30 \mathrm{~min}$ at $37^{\circ} \mathrm{C}$. The conjugate was diluted $1: 1000$ in the same buffer as in (3).

5. Enzyme reaction with the substrate o-phenylenediamine in citrate-phosphate buffer, $\mathrm{pH}$ 5.0, for $15 \mathrm{~min}$ and termination of the reaction with $1 \mathrm{~mol} / \mathrm{I} \mathrm{H}_{2} \mathrm{SO}_{4}$.

All reagents and samples were dispensed in $100 \mu$ volumen, and each of the steps $1-4$ was followed by washing 3 times with PBS-0.05\% Tween 20. Washing after step 4 included a final short rinse in citrate-phosphate buffer, $\mathrm{pH}$ 5.0. Plates were either 


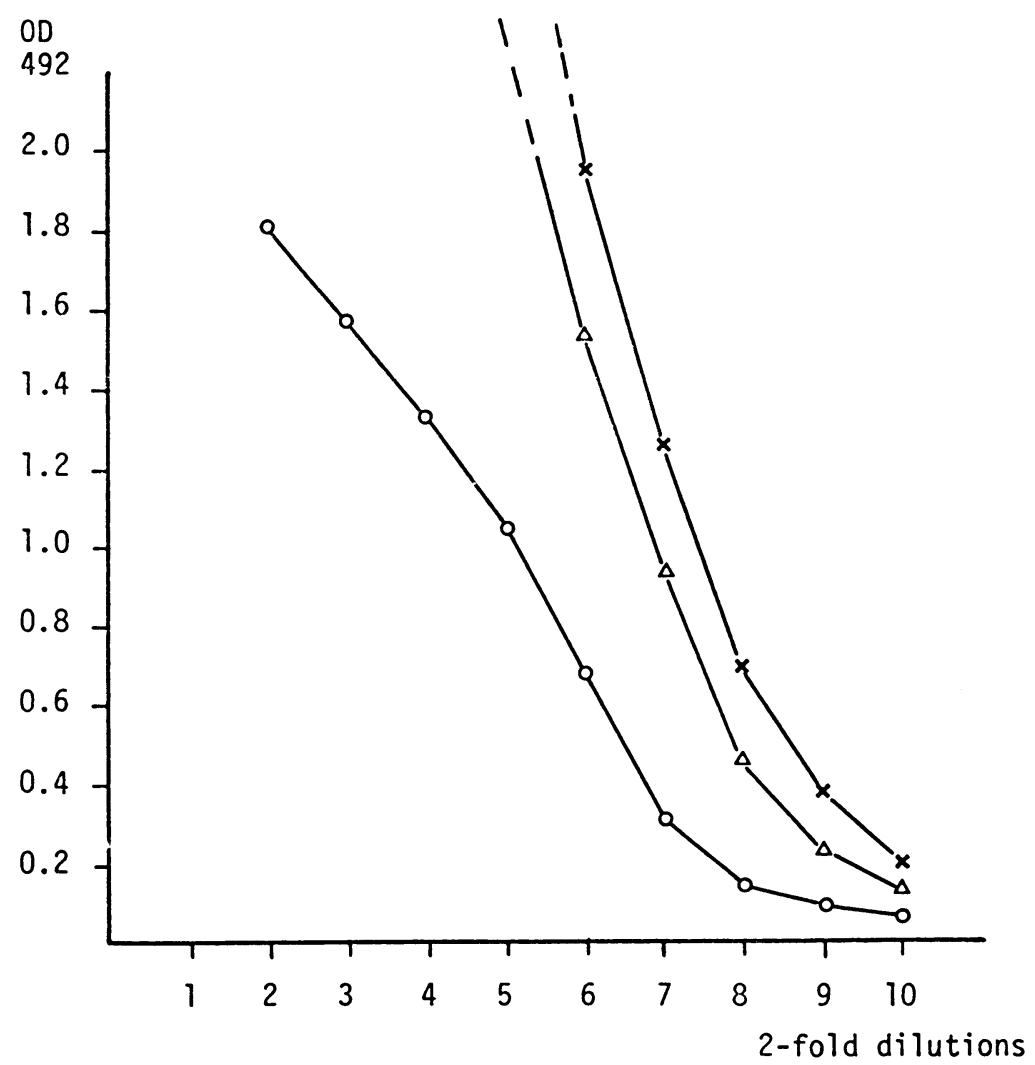

F i g u re 2 b.

read visually or measured at $492 \mathrm{~nm}$ in a multiscan spectrophotometer.

In some experiments rabbit IgG and guinea pig IgG were applied in reversed order. In these experiments conditions were as described above, except that peroxidase-conjugated anti-rabbit IgG was used at a dilution of 1:400 in PBS-0.05\% Tween 20 containing $10 \%$ normal bovine serum and $5 \%$ normal guinea pig serum to eliminate cross-reactivity between rabbit and guinea pig IgG.

\section{Complement fixation}

Suspensions prepared from epithelium were heat-inactivated at $56^{\circ} \mathrm{C}$ for $30 \mathrm{~min}$ before examination. The $\mathrm{CF}$ test was carried out in tubes using a constant amount of hyperimmune guinea pig serum and four $100 \%$ hemolytic units of complement (Traub \& Möhlmann 1943). 


\section{RESULTS}

\section{Characterization of the sandwich ELISA}

The rabbit sera used to establish a double sandwich test for types 0, A and C had neutralizing titres of 256-1024 and did not exhibit cross-neutralizing activity. When preparations of $146 \mathrm{~S}$ particles of each type were titrated in type $O$, A and C ELISA, a considerable cross-reactivity was observed for all three virus types. The cross-reactivity was most pronounced with $\mathrm{O}_{1} \mathrm{BFS}$ virus. This virus was therefore used in a more detailed study of type specificity in the ELISA.

The titration of $\mathrm{O}_{1}$ BFS $146 \mathrm{~S}$ particles in sandwich ELISA using guinea pig IgG as catching antibody is shown in Fig. 1a. The same virus preparation was also titrated after heat-degradation to $12 \mathrm{~S}$ subunits (Fig. 1a). It is seen that $12 \mathrm{~S}$ subunits titrate approximately 4 times more efficiently than $146 \mathrm{~S}$ particles, a finding that has been consistently observed and which is also seen when rabbit IgG is used as catching antibody. In Fig. $1 \mathrm{a}$ the buffer for rabbit antiserum and conjugate was PBS-Tween 20 containing $10 \%$ normal bovine serum and $5 \%$ normal guinea pig serum. The titrations of $146 \mathrm{~S}$ particles and $12 \mathrm{~S}$ subunits were simultaneously performed with buffers containing hyperimmune guinea pig serum of types A and $\mathrm{C}(2.5 \%$ of each) instead of normal guinea pig serum. The results are shown in Fig. $1 \mathrm{~b}$. Inclusion of heterologous hyperimmune guinea pig sera caused a displacement to the left of the titration curve for both $146 \mathrm{~S}$ particles and $12 \mathrm{~S}$ subunits. However, the curve for $146 \mathrm{~S}$ particles showed only a slight, although consistent, left-displacement, whereas that of $12 \mathrm{~S}$ subunits showed a displacement virtually superimposing it onto the corresponding $146 \mathrm{~S}$ curve.

To further illustrate the differential behaviour of $146 \mathrm{~S}$ particles and $12 \mathrm{~S}$ subunits in this type of ELISA, Figs. 2a and $b$ show titrations of $\mathrm{O}_{1}$ BFS $146 \mathrm{~S}$ particles and $12 \mathrm{~S}$ subunits with guinea pig type $\mathrm{O}$ catching antibody and using either homologous rabbit antiserum type $O$ or rabbit antiserum type $C$. Furthermore, the titrations with homologous antiserum in the presence of excess heterologous hyperimmune guinea pig sera are included. The titration of $146 \mathrm{~S}$ particles (Fig. 2a) shows a great difference between the curves for homologous and heterologous rabbit antiserum, and a small left-displacement of the homologous 


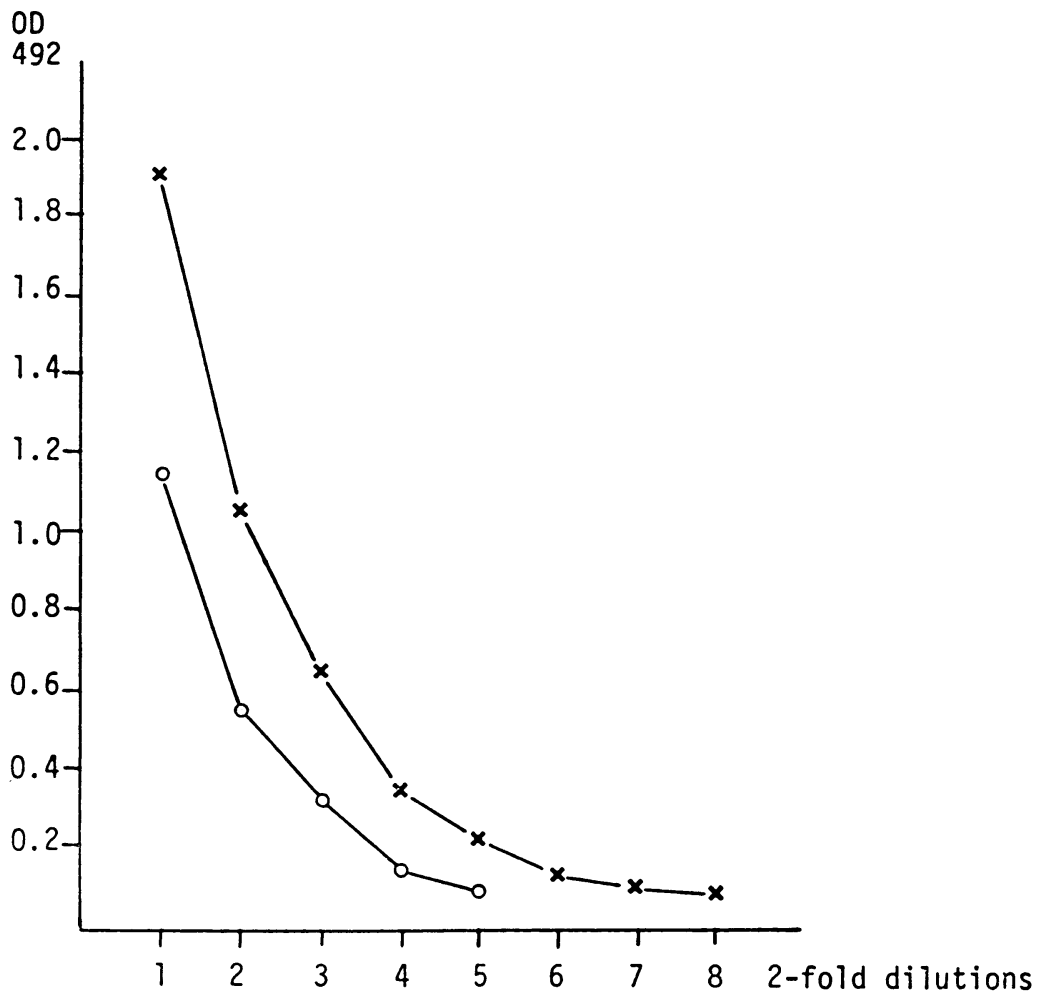

$\mathrm{Figure} 3$. Titration of $\mathrm{O}_{1} \mathrm{BFS} 146 \mathrm{~S}$ particles by direct adsorption to the microplate in carbonate buffer $\mathrm{pH} 9.6$ for $1 \mathrm{~h}$ at $37^{\circ} \mathrm{C}$. Rabbit antiserum $\mathrm{O}_{1} \mathrm{BFS}$ diluted in buffer containing normal guinea pig serum $(X-X)$ of hyperimmune guinea pig serum type $A$ and $C$ $(\mathrm{O} \longrightarrow \mathrm{O})$. The preparation of $146 \mathrm{~S}$ particles is the same as that shown in fig. 2 a. The first dilution contained $0.5 \mu \mathrm{g} / \mathrm{ml}$ of $146 \mathrm{~S}$ particles.

curve in the presence of heterologous hyperimmune guinea pig serum. Conversely, the titration of $12 \mathrm{~S}$ subunits (Fig. 2b) shows only slight difference between the curves obtained with homologous and heterologous rabbit antiserum, but a greater left-displacement of the homologous curve in the presence of heterologous hyperimmune guinea pig serum. The titration of $\mathrm{O}_{1} \mathrm{BFS}$ $12 \mathrm{~S}$ subunits has also been performed with guinea pig catching antibody type $\mathrm{C}$ and rabbit antibodies type $\mathrm{O}$ and $\mathrm{C}$, respectively. The results were essentially similar to those obtained when using guinea pig catching antibody type $O$ (Fig. 2b), except that both curves were slightly more displaced to the left (results not shown). 


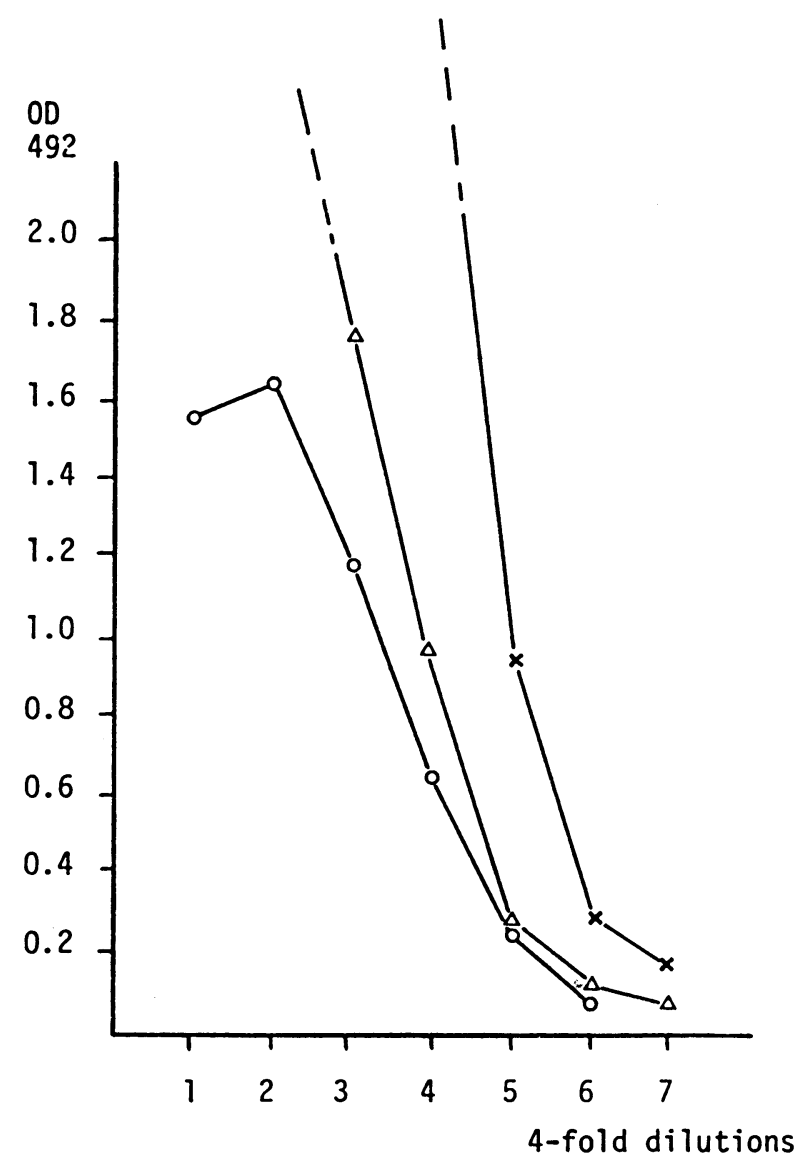

F ig u r e 4 a-c. Parallel titrations of $12 \mathrm{~S}$ preparations of sucrose gradient purified $146 \mathrm{~S}$ particles of $\mathrm{O}_{1}$ (a), $\mathrm{A}_{10}$ (b) and $\mathrm{C}$ (c) virus in type $O, A$ and $C$ sandwich ELISA using rabbit IgG as catching antibody (step 1) and guinea pig IgG in step $3 . \times-\times$ type O ELISA, $\mathrm{O} \longrightarrow \mathrm{O}$ type A ELISA, $\triangle \longrightarrow \triangle$ type C ELISA.

The titrations shown in Fig. 2a were done with a fresh preparation of $146 \mathrm{~S}$ particles that had not been subject to freezing. A parallel titration was made with a sample of this preparation that had been frozen once at $-80^{\circ} \mathrm{C}$. This showed that one cycle of freeze-thawing caused a significant increase in cross-reactivity, as determined by left-displacement of the titration curve after addtion of heterologous guinea pig hyperimmune sera and also by titration with heterologous rabbit antiserum (results not shown). A similar change was also noted when $146 \mathrm{~S}$ particles 


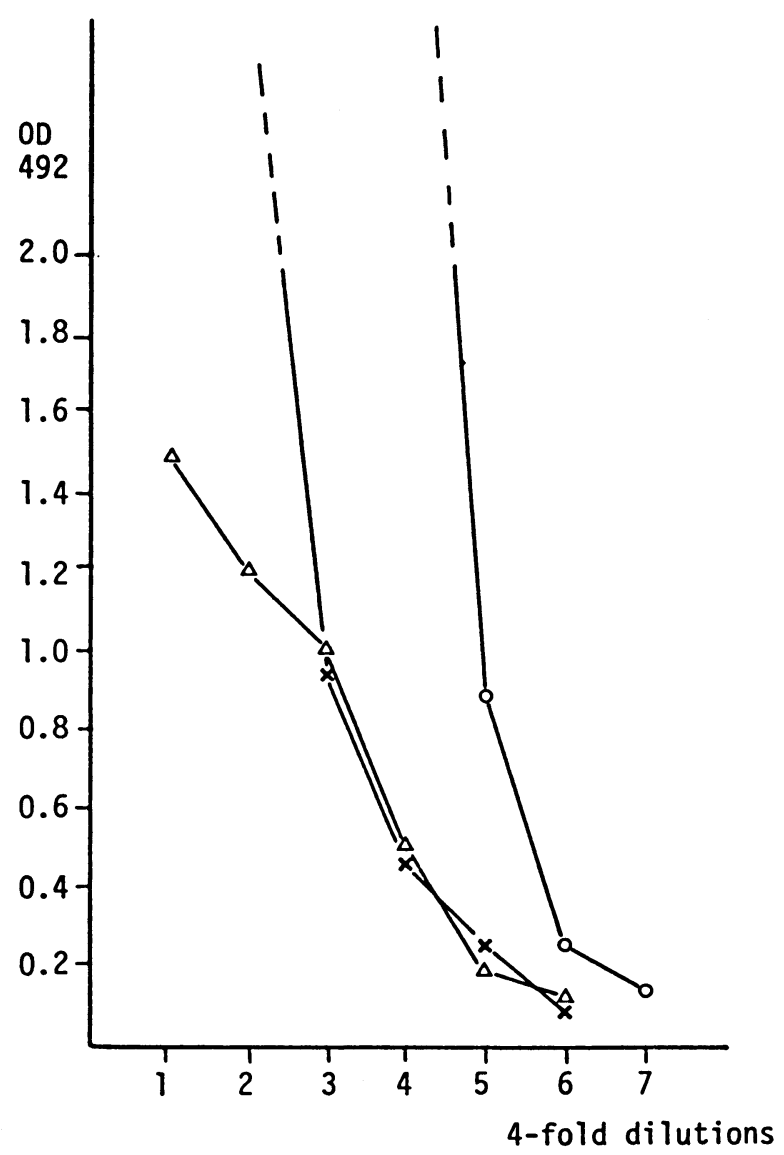

Fig u re 4 b.

were titrated by direct adsorption to the microplate in carbonate buffer, pH 9.6 (Fig. 3). Fig. 4a-c show the titration of $12 \mathrm{~S} \mathrm{sub-}$ units of types $O, A$ and $C$ in ELISA employing rabbit antisera as catching antibody. It can be seen that even with $12 \mathrm{~S}$ subunits of these virus strains, there is a clear typing with all 3 types.

A few typing experiments have been carried out with immunoplates and flexible polyvinyl plates in parallel. No difference was observed in absorbance readings between plates. However, the polyvinyl plates proved easier to read visually.

Application to field samples and comparison with a CF test

In Fig. 5 the parallel titrations in CF test and ELISA of epithelial samples of types $\mathrm{O}, \mathrm{A}$ and $\mathrm{C}$ are shown. If, arbitrarily, 


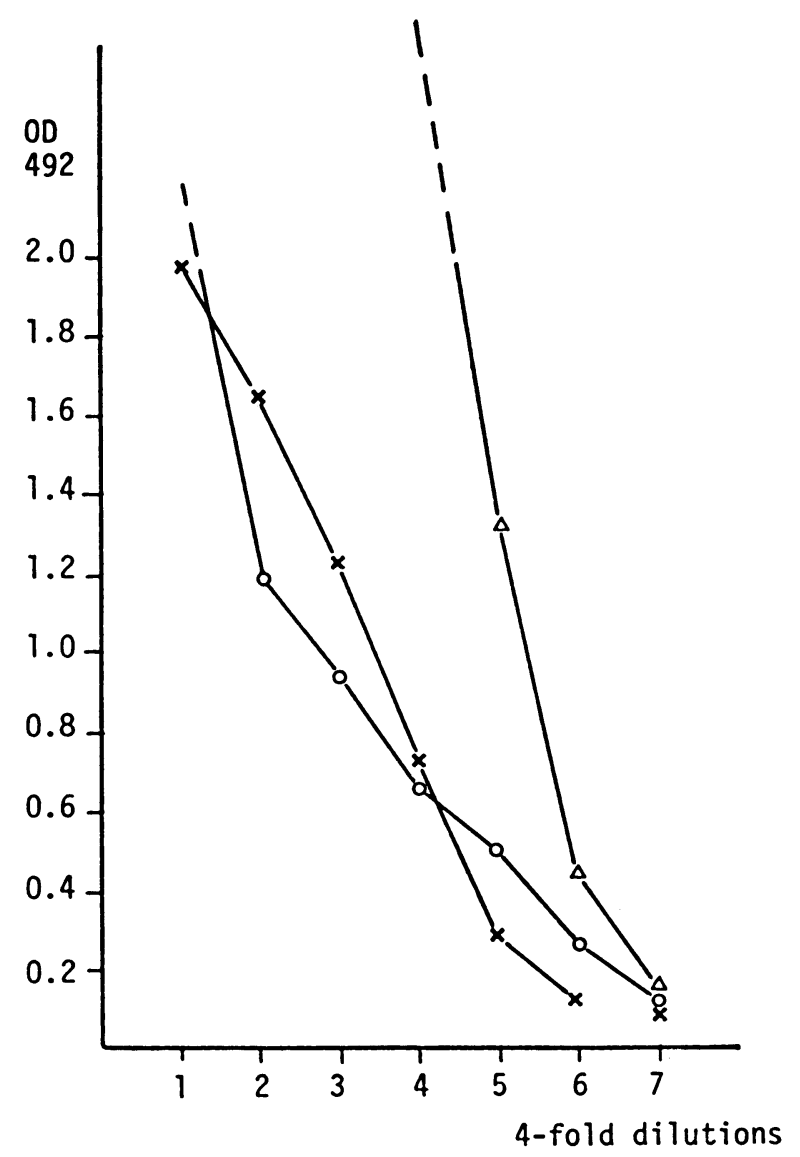

Figure 4 c.

values above 5 times background (hyperimmune serum without antigen and/or normal serum plus antigen) are considered significant, it follows that the ELISA is approximately 500 times more sensitive than the CF test.

From March 1982 until January 1983 twenty-one Danish field samples of type $O$ were examined by $C F$ and ELISA. The epithelial suspensions were not heat-treated before examination in ELISA. Of 21 samples, 19 were positive in both tests, whereas 2 samples were positive in ELISA only. One of these samples was confirmed by CF after passage in primary bovine kidney cells, whereas the remainder was verified by $\mathrm{CF}$ after submission of an additional sample. 


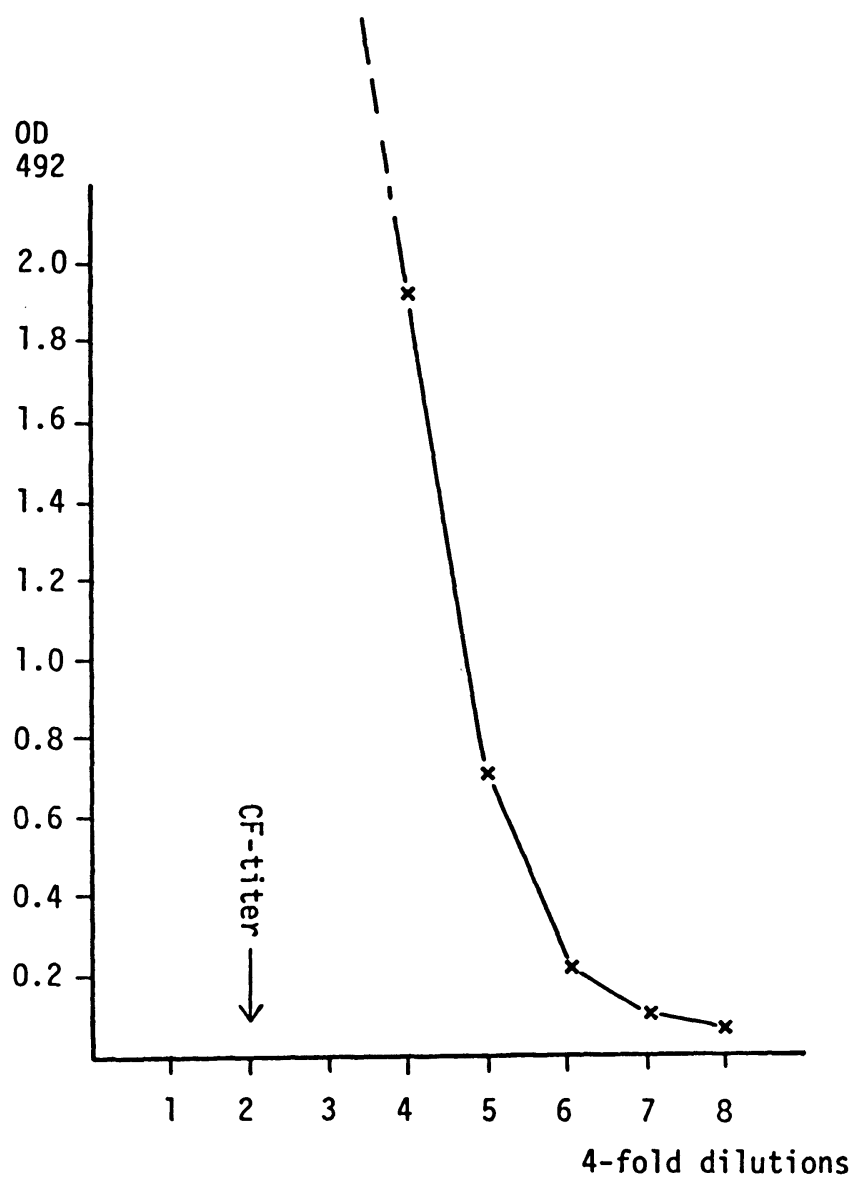

F i g u r e 5 a-c. Comparison of the CF test and ELISA. Epithelial suspensions of $O_{1}$ (a) $A_{5}$ (b) and $C$ (c) were examined by CF (2-fold dilutions, heat-inactivated) and ELISA (4-fold dilutions). The arrow indicates CF titre. The ELISA was performed with homologous antisera using rabbit IgG as catching antibody.

A large number of FMD virus negative samples has been examined by the 2 tcsts or, when only very small samples were available, by ELISA and inoculation of cell cultures. These include samples containing BVD virus and herpes mammilitis virus and samples most probably originating from various physical injuries. None of these samples gave significant reactions in any of the tests, which for the ELISA means absorbance values within 2-fold of control values. 


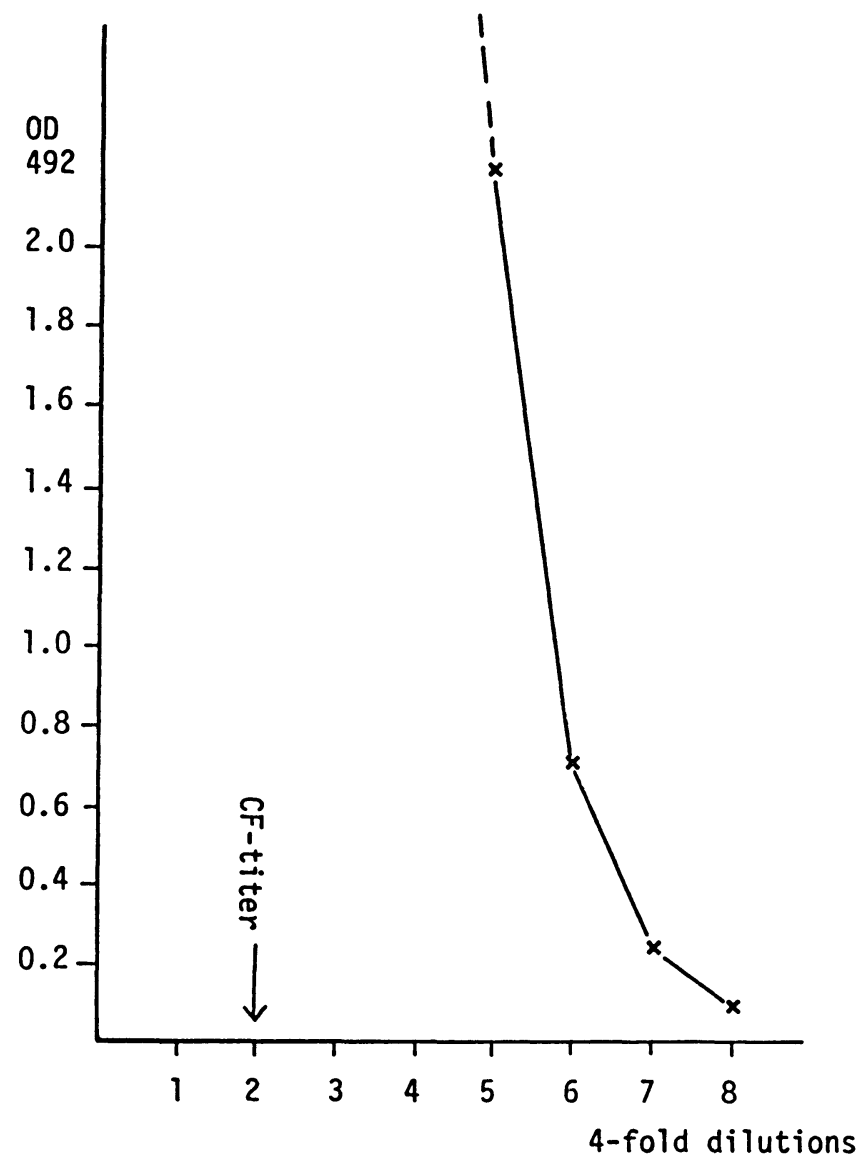

Figure 5 b.

\section{DISCUSSION}

From the results presented above it is evident that sensitivity and type specificity are to some extent complementary features, i. e. maximum sensitivity and type specificity cannot both be achieved within the same diagnostic test. As to the primary diagnosis of FMD, sensitivity should be given priority and, in particular, the test should not be limited to detection of $146 \mathrm{~S}$ particles since these can be expected to constitute only a minor fraction of the antigens in samples collected under adverse field conditions. For these reasons the results in Fig. 4 were produced with $12 \mathrm{~S}$ subunits rather than with intact particles.

A prominent finding during this work has been the unexpected behaviour of $146 \mathrm{~S}$ particles and $12 \mathrm{~S}$ subunits in our 


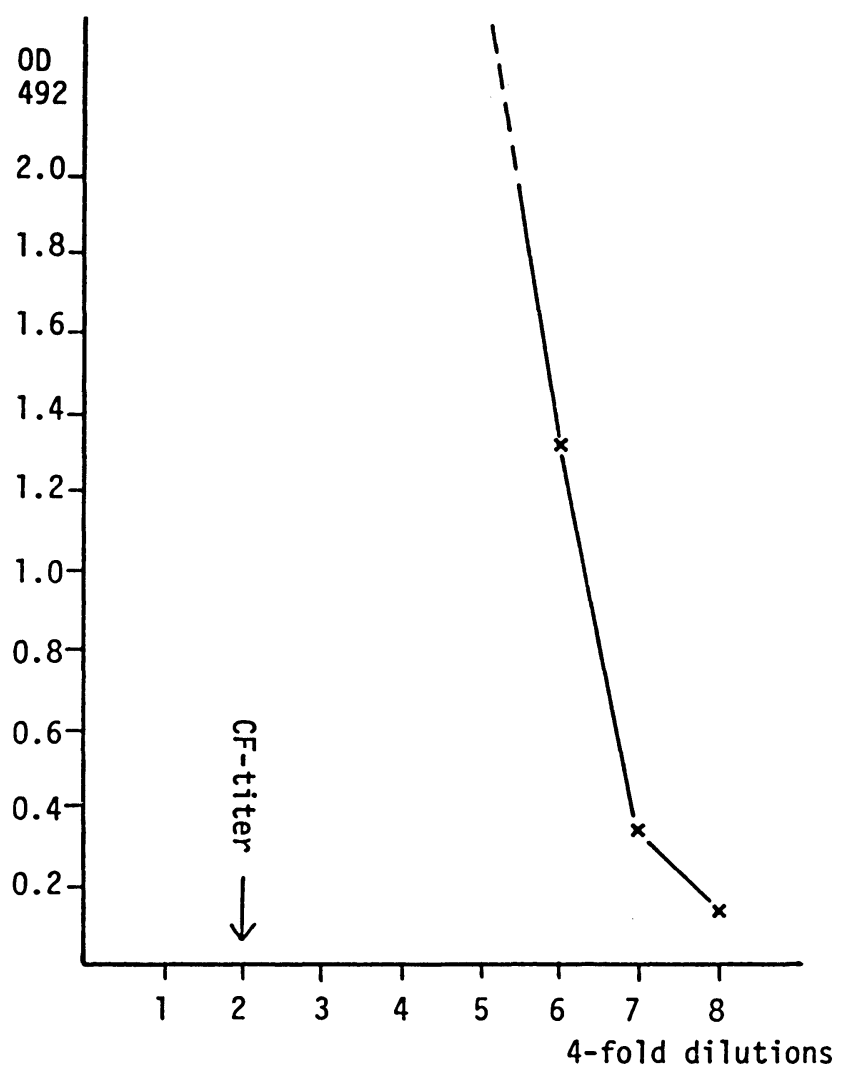

Figure 5 c.

sandwich ELISA compared to results previously published by others (Crowther \& Abu Elzein 1979 a, Abu Elzein \& Crowther 1979, Ouldridge et al. 1982). These authors have described sandwich techniques specifically detecting $146 \mathrm{~S}$ particles in the presence of $12 \mathrm{~S}$ subunits and VIA antigens. In contrast, the sandwich ELISA described here detects $12 \mathrm{~S}$ subunits about 4 times more efficiently than $146 \mathrm{~S}$ particles. The explanation for this striking difference is unknown, but may be related to differences in selection and preparation of antisera and/or differences in the preparation of $12 \mathrm{~S}$ subunits (heat vs. acid degradation). From the data presented here it can be concluded that the increased reaction of $12 \mathrm{~S}$ subunits is mainly due to the appearance of cross-reacting determinants, while quantitatively retaining the type-specific response. These cross-reacting determinants appear to be spatially distributed over the $12 \mathrm{~S}$ subunit in such a way 
that they can efficiently participate in the formation of a double sandwich formed by heterologous antibody molecules.

Recent evidence (Cartwright et al. 1980, Meloen \& Briaire 1980, Hardy \& Moore 1981, McCullough \& Butcher 1982) has substantiated the serological relationship between $146 \mathrm{~S}$ particles and $12 \mathrm{~S}$ subunits to the point that intact particles are considered to expose mainly, if not exclusively, type-specific determinants, some of which are unique to $146 \mathrm{~S}$ particles while others are shared with $12 \mathrm{~S}$ subunits. These findings are relevant in terms of designing a suitable ELISA for any specific purpose. For the primary diagnosis of FMD a broadly reacting test would appear to be ideal, whereas subtyping assays would perform better with a minimized cross-reactivity between types.

The cross-reactions seen in this study with purified preparations of $146 \mathrm{~S}$ particles are most likely explained by slight degradation or conformational change of intact particles before and during incubation in the microplate. This explanation would be in accordance with the observation that purified $146 \mathrm{~S}$ particles demonstrate cross--reactivity upon exposure to the plastic surface (Meloen \& Briaire 1980).

The first series of experiments with ELISA was done with polystyrene microplates (NUNC) and unfractionated guinea pig hyperimmune serum. After the introduction of immunoplates (NUNC) it was found that these had a higher and more uniform adsorptive capacity resulting in less variation within and between individual plates. When these plates were tested under our standard conditions, it became apparent that background values of optical density were considerably increased compared to the other type of microplate. However, this was only seen with hyperimmune guinea pig sera that had been heat-inactivated and not with normal unheated guinea pig serum. Since heat-inactivation of normal guinea pig serum resulted in background values comparable to those seen with heat-inactivated hyperimmune serum, it was anticipated that high-molecular weight IgG aggregates, formed during heat-inactivation, might be responsible for this. As the monomeric IgG fraction collected after gel filtration of ammonium sulphate precipitates had lost the non-specific binding seen with whole serum this fraction was used instead of whole serum. Preliminary experiments with these preparations of monomeric IgG indicate that they should not be stored frozen, as this leads to slightly higher non-specific binding compared to storage at $4^{\circ} \mathrm{C}$. 
Further control experiments have shown that absorption of rabbit catching antibody with insolubilized guinea pig serum and addition of $5 \%$ normal rabbit serum to the diluents for guinea pig IgG and conjugate each resulted in slightly lower background values, the overall result being a reduction of background values from approximately 0.5 to reproducible values of 0.05 . From titrations of type $O$ epithelial samples before and after these modifications, including the shift to immunoplates, it is estimated that an 8-fold increase in sensitivity has been obtained.

The present comparison between CF and ELISA using epithelial samples of type $\mathrm{O}, \mathrm{A}$ and $\mathrm{C}$ showed the ELISA to be approximately 500 times more sensitive than our routine CF test. This figure is 5-10 times higher than that previously published (Crowther \& Abu Elzein 1979 b) using purified $146 \mathrm{~S}$ preparations for comparison.

During the outbreaks of FMD in Denmark in 1982 and 1983, the ELISA was used in parallel with CF in routine diagnostic work. The experience gathered so far can be summarized as follows: A positive diagnosis in both tests clearly reduces the risk of a false positive diagnosis. The higher sensitivity of ELISA has in a few instances been significant for an early positive diagnosis. The ELISA is especially useful when only small field samples are available. Finally, the higher sensitivity of ELISA allows a stronger and more confident attitude towards rejection of suspect, but non-FMD, cases, especially if the samples submitted are of vesicular origin.

\section{REFERENCES}

Abu Elzein, E. M. E. \& J. R. Crowther: The specific detection of footand-mouth disease virus whole particle antigen $(140 \mathrm{~S})$ by enzyme labelled immunosorbent assay. J. Hyg. 1979, 83, 127-134.

Cartwright, B., W. G. Chapman \& F. Brown: Serological and immunological relationship between the $146 \mathrm{~S}$ and $12 \mathrm{~S}$ particles of foot-and-mouth disease virus. J. gen. Virol. 1980, 50, 369-375.

Crowther, J. R. \& E. M. E. Abu Elzein: Application of the enzyme-linked immunosorbent assay to the detection and identification of foot-and-mouth viruses. J. Hyg. 1979a, 83, 513-519.

Crowther, J.R.\& E.M.E. Abu Elzein: Detection and quantification of foot-and-mouth disease virus by enzyme-linked immunosorbent assay techniques. J. gen. Virol. 1979b, 42, 579-602.

Hardy, M. M. \& D. Moore: Neutralization of foot-and-mouth disease virus. I. Sensitization of the $140 \mathrm{~S}$ virion by antibody also reactive with the $12 \mathrm{~S}$ protein subunit. J. gen. Virol. 1981, 55, $415-427$. 
$L e i, J . C .:$ Report of the session of the research group of the standing committee of the European commission for the control of FMD. Uccle, Belgium, FAO, Rome, 1978.

McCullough, K. C. \& R. Butcher: Monoclonal antibodies against footand-mouth disease virus $146 \mathrm{~S}$ and $12 \mathrm{~S}$ particles. Arch. Virol. 1982, 74, 1-9.

Meloen, R. H. \& F. Briaire: A study of the cross-reacting antigens on the intact foot-and-mouth disease virus and its $12 \mathrm{~S}$ subunits with antisera against the structural proteins. J. gen. Virol. 1980, $51,107-116$.

Ouldridge, E. P. Barnett \& M. M. Rweyemamu: The relative efficiency of two ELISA techniques for the titration of FMD antigen. In: THE ELISA: Enzyme-linked immunosorbent assay in veterinary research and diagnosis (ed. R. C. Wardly \& J. R. Crowther). Current topics in veterinary medicine and animal science vol. 22. Martinus Nijhoff Publ. The Hague 1982.

Schjerning-Thiesen, K.: Differentiation of virus types in foot-andmouth disease (FMD). Acta vet. Scand. 1964, 5, 133-145.

Ternynck, T. \& S. Avrameas: Polymerization and immobilization of proteins using ethylchloroformate and glutaraldehyde. Scan. J. Immunol. suppl. 1976, 3, 29-35.

Traub, E. \& H. Möhlmann: Typebestimmung bei maul- und klauenseuche mit hilfe der komplementbindungsprobe. (Typing of footand-mouth disease by complement fixation). Z. Bl. Bakt. Abt. I. $1943,150,289-310$.

\section{SAMMENDRAG}

En ELISA til diagnosticering af mund-og-klovesyge.

Karakterisering og sammenligning med komplementbinding.

Der beskrives en sandwich ELISA til påvisning af mund- og klovesygevirus type $\mathrm{O}, \mathrm{A}$ og $\mathrm{C}$ ved hjælp af hyperimmune marsvinesera og kaninsera fremstillet ved immunisering med rensede $146 \mathrm{~S}$ viruspartikler. Metoden fandtes velegnet til påvisning af både intakte $146 \mathrm{~S}$ viruspartikler og degraderede viruspartikler (12 S partikler).

ELISA teknikken var ca. 500 gange så følsom som komplementbindingsprøven til påvisning af mund- og klovesygevirus (antigen) i aftemateriale.

I 19 ud af 21 verificerede tilfælde var det muligt at stille en tidlig mund- og klovesyge diagnose ved både komplementbinding og ELISA. I de to sidste tilfælde blev en tidlig diagnose alene stillet ved ELISA.

\section{(Received April 10, 1984).}

Reprints may be requested from: P. Have, the State Veterinary Institute for Virus Research, Lindholm, DK-4771 Kalvehave, Denmark. 